\title{
Absence of Middle Hepatic Vein Combined with Retro-Aortic Left Renal Vein: a Very Rare Case Report
}

\author{
Ozan Turamanlar ${ }^{1}$, Oğuz Kırpıko², Oğuz Aslan Özen³, Bumin Değirmenci², Sezer Akçer', Ramazan Uygur \\ 'Department of Anatomy, Faculty of Medicine, Afyon Kocatepe University, Afyonkarahisar, Turkey \\ ${ }^{2}$ Department of Radiology, Faculty of Medicine, Afyon Kocatepe University, Afyonkarahisar, Turkey \\ ${ }^{3}$ Department of Anatomy, Faculty of Medicine, Namık Kemal University, Tekirdağ, Turkey
}

\begin{abstract}
The hepatic and renal veins drain into the inferior vena cava. The upper group of hepatic veins consists of three veins which extend to the posterior face of the liver to join the inferior cava. The left renal vein passes anterior to the aorta just below the origin of the superior mesenteric artery. We detected a variation in the hepatic and renal veins in a multislice CT angiogram of a nine-year-old male patient in the Radiology Department of Afyon Kocatepe University Medical School. The upper group hepatic veins normally drains into the inferior vena cava as three separate trunks, namely the right, left and middle. In our case, we found that only the right and left hepatic veins existed and the middle hepatic vein was absent. Furthermore, the left renal vein, which normally passes anterior to the abdominal aorta, was retro-aortic. Left renal vein variations are of great importance in planning retroperitoneal surgery and vascular interventions. Knowledge of a patient's hepatic vein and renovascular anatomy and determining their variations and anomalies are of critical importance to abdominal operations, transplantations and preoperative evaluation of endovascular interventions.
\end{abstract}

Key Words: Variation, middle hepatic vein, left renal vein, CT

Received: 13.12 .2011

Accepted: 02.03.2012

\section{Introduction}

The hepatic and renal veins drain into the inferior vena cava. The upper group of hepatic veins consists of three veins and these extend to the posterior face of the liver to join the inferior vena cava (Figure 1). The complexities of liver surgery and advances in operation techniques involving the liver have made variations in this region more important (1). The left renal vein passes anterior to the aorta just below the origin of superior mesenteric artery. Knowledge of a patient's left renal vein anomalies is important in planning retroperitoneal surgery and vascular interventions and also in the differential diagnosis of retroperitoneal lymphadenopathies (2).

\section{Case Report}

We detected a variation in the hepatic and renal veins in the multislice CT angiogram of a nine-year-old male patient in Radiology Department of Afyon Kocatepe University Medical School. The CT angiogram was performed using a Philips Brilliance CT (Philips Medical Systems, Netherlands). The upper group hepatic veins normally drain into the inferior vena cava as three separate trunks, namely the right, left and middle. In our case, we found that only the right and left hepatic veins existed and the middle hepatic vein (MHV) was absent (Figure 2). Furthermore, the left renal vein was retro-aortic (Figure 3).

\section{Discussion}

The definitive portal vein originates from the two vitelline veins (and the intervitelline anastomosis) and from the left umbilical vein. At the end of the complex process occurring between the third and the sixth week of embryological development, the trunk of the portal vein is formed by the interconnected vitelline veins (3).

The embryological development of the hepatic parenchyma takes place independently within the development of the vascular system. After the $35^{\text {th }}$ day of gestation, the development of the vascular system has to adapt to the rapid growth of the hepatic parenchyma; allometric development makes the left lobe of the liver smaller than the right lobe (4).

During the fifth to the seventh week, a number of additional veins are formed: (a) the subcardinal veins, which mainly drain the kidneys; (b) the sacrocardinal veins, which drain the lower extremities and (c) the supracardinal veins, which drain the body wall by way of the intercostal veins, taking over the functions of the posterior cardinal veins. The anastomosis between the subcardinal veins forms the left renal vein. When this communication has been established, the left subcardinal vein disappears, and only its distal portion remains as the left gonadal vein. Hence, the right subcardinal vein becomes the main drainage channel and develops into the renal segment of the inferior vena cava (5). 


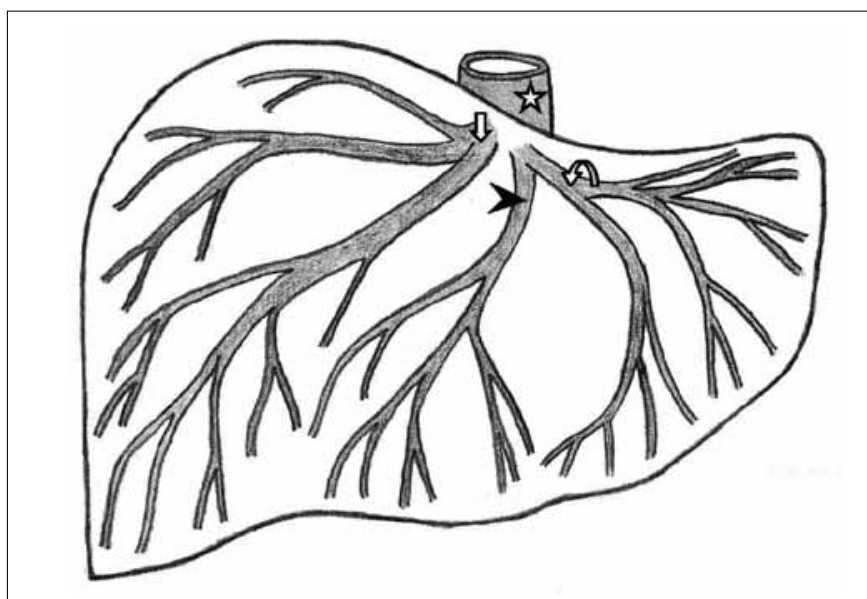

Figure 1. Schematic illustration of the normal anatomical distribution of hepatic veins. Right (arrow), middle (arrow head) and left (curved arrow) hepatic veins and the inferior vena cava (asterisk)

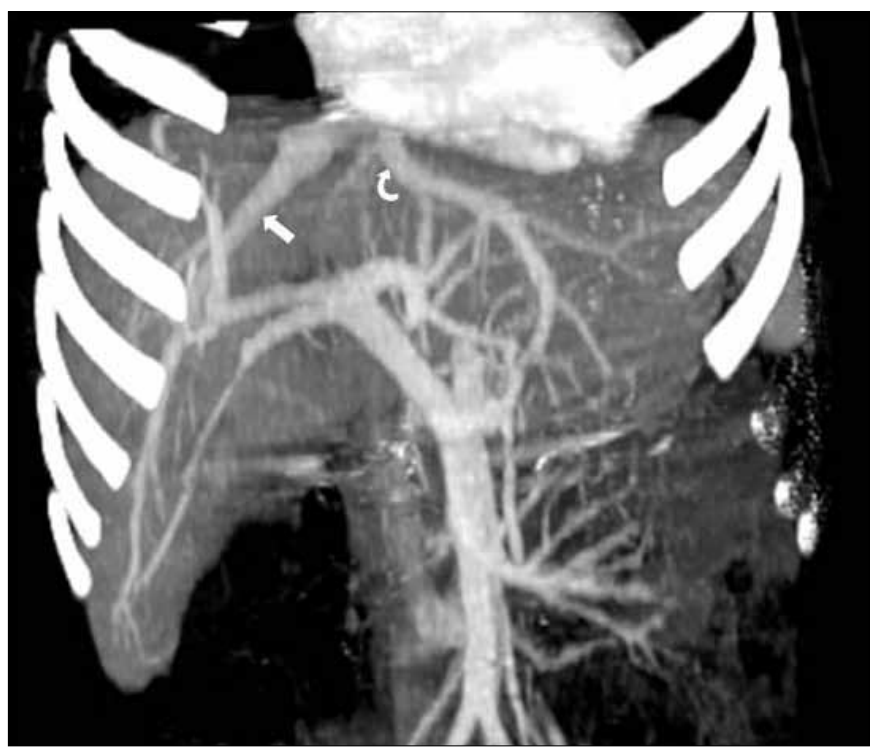

Figure 2. CT image shows the right (arrow) and left (curved arrow) hepatic veins

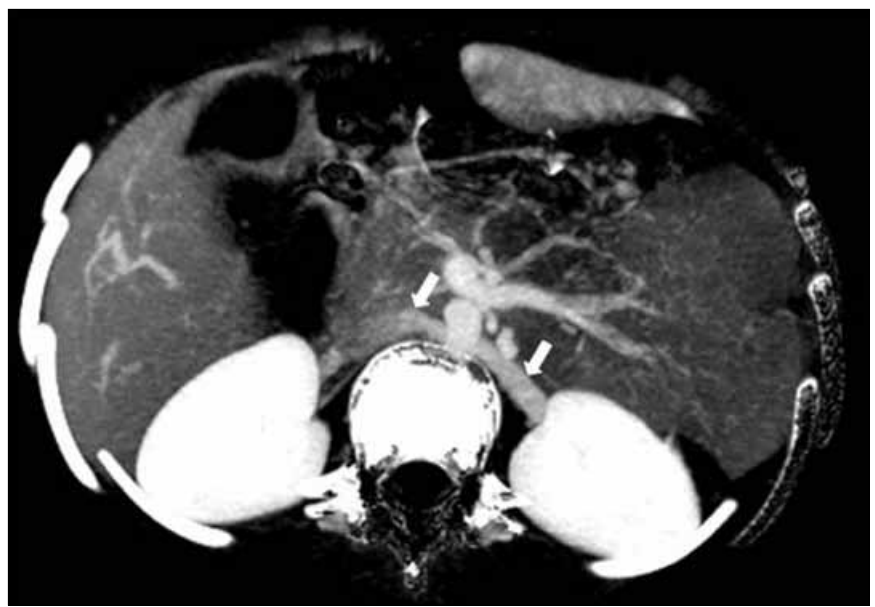

Figure 3. Axial CT image shows a retro-aortic left renal vein (arrows)
In right or left hepatectomy for living donor liver transplantation, the MHV lying in the mid-plane is an important landmark and guide for precise liver transection (6). The surgical plane courses $1 \mathrm{~cm}$ to the right of the MHV in cases of right lobe dissection. In the right liver graft donor operation including the MHV, the MHV has to be exposed and followed in the transection plane so that minimal necrotic tissue is left on the graft surface. For the left liver graft donor operation, the MHV is followed so that the transection will not approach and damage the right anterior portal pedicle (7). Knowledge of vascular anatomy and variations therein helps avoid undue damage to the transplanted and remnant liver. Important hepatic venous variations affecting both donors and recipients are seen in some patients, thus posing a challenge for the surgeon, and may result in a modification of the hepatectomy plane (8).

We could not find a variation similar to our case in the literature. There was only one report demonstrating the absence of the middle hepatic vein (6). Fan and Wong reported a right liver donor in whom the MHV was absent and not encountered during liver transection along the midplane of the liver.

The frequency of retro-aortic left renal vein ranges from $0.5 \%$ to $5.7 \%(2,9-12)$. In a study by Karaman et al. (11), 63 (3.6\%) of 1856 patients showed a retro-aortic left renal vein and 44 of these 63 patients had urologic symptoms (hematuria, flank and abdominal pain, left gonadal vein varicocele). Mendizabal et al. reported nine cases with hematuria, in patients aged between 8-15 years, two of whom had retro-aortic left renal vein (13). Multislice CT angiography revealed a fistula between the retro-aortic left renal vein and an infra-renal aortic aneurysm in a patient who had left flank pain, hematuria and acute renal failure (14). Arslan et al. (15) investigated the incidence of retro-aortic left renal vein and its relationship with varicocele. They found that seven of nine male patients with a retro-aortic left renal vein had varicocele of varying degrees. Karazincir et al. (16) observed a retro-aortic left renal vein in 13 (9.3\%) of 140 patients with varicocele. According to Yagci et al. (17), varicocele and retro-aortic left renal vein may be associated. A patient who had a one-year history of recurring right flank pain, dysuria, hematuria and fever underwent CT and MR venography which showed a retro-aortic left renal vein joining the left common iliac vein (18). In a study by Karaman et al. (11), three of 1856 patients had the same anomaly. McAllister et al. (19) reported a case of renal cell carcinoma extension into a retro-aortic left renal vein and a tumor thrombus in the same vessel. Likewise, Pinsk et al. (20) reported a case of tumor thrombus in a retro-aortic left renal vein. Washecka et al. (21) presented a case of postpartum renal vein thrombosis with a left retro-aortic renal vein. A left retro-aortic renal vein may also be seen with other complex venous anomalies and may cause primary Budd-Chiari Syndrome (22). The small number of papers reporting the absence of the middle hepatic vein, the rare occurrence of retro-aortic renal vein and the clinical symptoms that may accompany these venous anomalies emphasize the originality and importance of our case.

We think that knowledge of variations in this region is essential for correct diagnosis and treatment. The very rare variation presented here may also contribute to the effectiveness of surgical interventions. 


\section{Conflict of Interest}

No conflict of interest was declared by the authors.

\section{References}

1. Oguzkurt L, Ozkan U, Ulusan S, Koc Z, Tercan F. Portal vein variations: clinical implications and frequencies in routine abdominal multidetector CT. Diagn Interv Radiol 2007;13:75-80.

2. Yeşildağ A, Adanir E, Köroğlu M, Baykal B, Oyar O, Gülsoy UK. Incidence of left renal vein anomalies in routine abdominal CT scans. Tani Girisim Radyol 2004;10:140-3.

3. Vanneuville G, Viallet JF, Garcier JM La veine porte. In: Chevrel JP (ed). Anatomie clinique. Berlin: Springer-Verlag 1994;455-66.

4. Collardeau-Frachon S, Scoazec JY. Vascular development and differentiation during human liver organogenesis. Anat Rec 2008;291:614-27. [CrossRef]

5. Sadler TW. Langman's Medical Embryology. 8th ed. Lippincott Williams \& Wilkins; 2000

6. Fan ST, Wong Y. Absent middle hepatic vein in a right liver graft donor. Hepatobiliary Pancreat Dis Int 2008;7:430-2.

7. Fan ST, Lo CM, Liu CL, Wang WX, Wong J. Safety and necessity of including the middle hepatic vein in the right lobe graft in adult-toadult live donor liver transplantation. Ann Surg 2003;238:137-48. [CrossRef]

8. Sahani D, Mehta A, Blake M, Prasad S, Harris G, Saini S. Preoperative hepatic vascular evaluation with $C T$ and MR angiography: implications for surgery. Radiographics 2004;24:1367-1380. [CrossRef]

9. Trigaux JP, Vandroogenbroek S, De Wispelaere JF, Lacrosse M, Jamart J. Congenital anomalies of the inferior vena cava and left renal vein: evaluation with spiral CT. J Vasc Interv Radiol 1998;9:339-45. [CrossRef]

10. Chai JW, Lee W, Yin YH, Jae HJ, Chung JW, Kim HH, et al. CT angiography for living kidney donors: accuracy, cause of misinterpretation and prevalence of variation. Korean J Radiol 2008;9:333-9. [CrossRef]
11. Karaman B, Koplay M, Ozturk E, Basekim CC, Ogul H, Mutlu H, et al. Retroaortic left renal vein: multidetector computed tomography angiography findings and its clinical importance. Acta Radiol 2007;48:355-60. [CrossRef]

12. Satyapal KS, Kalideen JM, Haffejee AA, Singh B, Robbs JV. Left renal vein variations. Surg Radiol Anat 1999;21:77-81. [CrossRef]

13. Mendizábal S, Román E, Serrano A, Berbel O, Simón J. Left renal vein hypertension syndrome. Nefrologia 2005;25:141-6.

14. Barrier P, Otal P, Garcia O, Vahdat O, Domenech B, Lannareix $\mathrm{V}$, et al. Aorta-left renal vein fistula complicating an aortic aneurysm: preoperative and postoperative multislice CT findings. Cardiovasc Intervent Radiol 2007;30:485-7. [CrossRef]

15. Arslan H, Etlik O, Ceylan K, Temizoz O, Harman M, Kavan M. Incidence of retro-aortic left renal vein and its relationship with varicocele. Eur Radiol 2005;15:1717-20. [CrossRef]

16. Karazincir S, Balci A, Görür S, Sumbas H, Kiper AN. Incidence of the retroaortic left renal vein in patients with varicocele. J Ultrasound Med 2007;26:601-4.

17. Yagci B, Tavasli B, Karabulut N, Kiroglu Y. Clinical significance and renal haemodynamics of incidentally detected retroaortic left renal vein: assessment with venous Doppler sonography. $\mathrm{Br} \mathrm{J} \mathrm{Ra}$ diol 2008;81:187-91. [CrossRef]

18. Brancatelli G, Galia M, Finazzo M, Sparacia G, Pardo S, Lagalla R. Retroaortic left renal vein joining the left common iliac vein. Eur Radiol 2000;10:1724-5. [CrossRef]

19. McAllister JD, Ross GJ, Samaha AM Jr. Retroaortic renal vein with tumor thrombus: MR findings. Urol Radiol 1992;13:170-2. [CrossRef]

20. Pinsk R, Nemcek AA Jr, Fitzgerald SW. Tumor thrombus in a retroaortic left renal vein and incidental right circumcaval ureter. Urol Radiol 1992;13:166-9. [CrossRef]

21. Washecka R, Hulnick DH, Catanese A, Farcon E. Postpartum renal vein thrombosis with left retroaortic renal vein. Urology 1987;29:548-51. [CrossRef]

22. Sakamoto N, Koizumi K, Asahina Y, Tazawa J, Maeda M, Marumo $F$, et al. Primary Budd-Chiari syndrome due to complex venous anomalies. Abdom Imaging 1997;22:499-501. [CrossRef] 